\title{
111 ナノインデンテーション試験によるセラミックス材料の特性評価 一室化ケイ素の硬度評価と連続転位モテルによる考察—
}

Evaluation of Mechanical Characteristics for Ceramic Materials by Nanoindentation Testing; - Nano-Hardness for $\mathrm{Si}_{3} \mathrm{~N}_{4}$ and its Estimation using Continuum Dislocation Model-
$\bigcirc$ 正 比嘉吉一 (阪大·院)
正 北川浩（阪大・院)
$\begin{array}{lll}\text { 学 板谷昌宏 } & \text { (阪大・院) } \\ \text { 正 } & \text { 中谷彰宏 } & \text { (阪大・院) }\end{array}$

Yoshikazu HIGA, Masahiro ITADANI, Hiroshi KITAGAWA and Akihiro NAKATANI

Department of Adaptive Machine Systems, Graduate School of Engineering, Osaka University, 2-1 Yamada-Oka, Suita, Osaka 565-0871

Key Words : Nanoindentation Testing, Polycrystalline $\mathrm{Si}_{3} \mathrm{~N}_{4}$, Mechanical Properties, Size Effect, Continuum Dislocation Model

\section{1 緒 言}

セラミックスは機械的に優れた性質を持っているも のの, 大きな塑性変形をともなうことなく破壊が起こ るため, 典型的なぜい性材料として知られている。 し かしながら, 極微小変形域では延性的な変形挙動を示 す多くの実験結果が報告されている(1)-(3)。一方，同 材料の機械的性質を評価する一手法としてサブミクロ ン・ナノオーダーの超微小押込みが可能な硬さ試験（ナ ノインデンテーション試験）が注目されている(4),(5). しかし，ナノインデンーション試験結果から押込み 深さが数 $\mu \mathrm{m}$ 以下となると硬さ值が上昇するという硬 さの寸法依存性変形挙動が報告されている(6).このよ うな中, 単結晶 $\mathrm{Si}$ および単結晶 $\mathrm{Al}$ に対するナノイン テンテーション試験より, 微小押込み時の硬度上昇に ついて圧子押込み時に生成する転位とその集団化挙動 に注目した研究が行われている(7).

本研究では, 多結晶セラミックス公化ケイ素に対す るナノインテンテーション試験を行い, 極微小変形下 における硬さの寸法依存性変形挙動について検討する. ついで, 同材料のナノインテンテーション試験時にお ける弾塑性変形挙動について検討を加えるため, 連続 転位モデルによる解析を行う。

$$
2 \text { ナノインデンテーション試験 }
$$

2.1 试料およひ実跧装目多結晶セラミックス窒化 ケイ素 $\left(\mathrm{Si}_{3} \mathrm{~N}_{4}\right)$ を試料とし，ダイヤモンド砥石で表面 平行を出した後, 粒径 $7,3,0.5 \mu \mathrm{m}$ のダイヤモンド ペーストにてバフ研磨を行い鏡面仕上を行った。

ナノインテンテーション試験は, 島津ダイナミック 超微小硬度計 DUH-201 を使用し，押込み圧子には三 角錐の Berkovich 型圧子（対稜角 $115^{\circ}$ ，ダイヤモン ド）を用いた. また, 圧子押込み後の試料に残留した 圧痕は島津製作所社製の原子間力顕微鏡 (AFM)SPM9500 により表面形状を計浿した. なお, 得られた試料 の表面粗さは十点平均粗さ $\left(R_{Z}\right)$ で約 $50 \mathrm{~nm}$ である.

2.2 试硂方法 2.1 で潐備した試料に対して, 最大 押込み荷重 $P_{\max }$ を $10 \sim 500 \mathrm{mN}$ の条件下でナノイン テンテーション試験を行った. 試験により得られる微 小硬度の評価には, Oliver らによる評価式を用いて算 出した(8).

\section{3 結 果}

試験荷重を 10,50 および $500 \mathrm{mN}$ とした場合に得ら れた荷重一変位関係（負荷除荷曲線）を図 1 に，実験 より得られた硬度一最大押込み変位の関係を図 2 に示
す. なお，図1 中の両軸とも試験時の最大荷重および 最大変位にて無次元化した. また, 除荷時のデータに ついては最小自乗近似にて曲線をグラフ中に付記して いる.

グラフから, 硬度評価に寄与する除荷初期過程の剛 性 $\left(d P_{\max } / d h_{c}\right) （ h_{c}$ : 接触深さ）は, $P_{\max }=10 \mathrm{mN}$ と した際に著しく低下することが分かる。これは，図2 中の押込み量 $h_{\max }<0.50 \mu \mathrm{m}$ の領域に対応しており, この領域から著しい硬度上昇を示すことが確認できる.

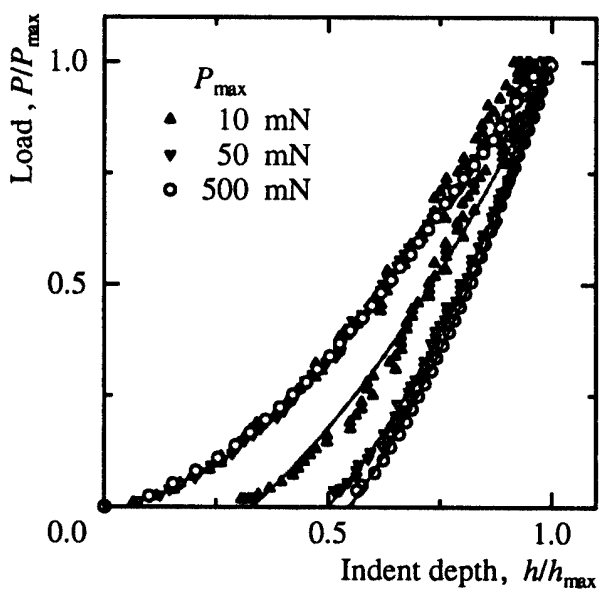

Fig.1 Normalized indent load and depth relation.

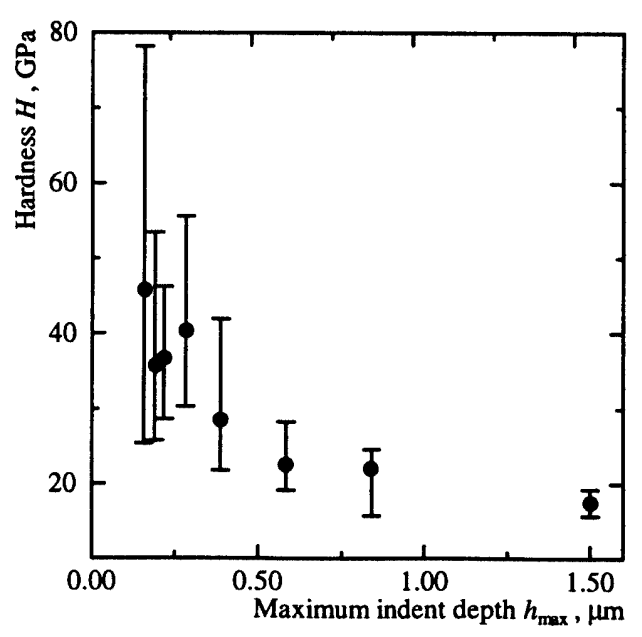

Fig.2 Microhardness of polycrystalline $\mathrm{Si}_{3} \mathrm{~N}_{4}$.

〔No.02-05〕日本機械学会材料力学部門講演会講演論文集〔2002-10.12 14,宇部市〕 


\section{4 窒化ケイ素の弾塑性変形挙動解析}

4.1 連続転位モデルによる解析 以下では, Berkovich 型圧子による多結晶セラミックス窒化ケイ 素のナノインデンテション試験により得られた負 荷一除荷曲線から連続転位モデルによる解析を行う。

本手法は, 圧子押込み時の塑性的押込み体積がプ リズマティック連続転位モデルよよパンチングによ り補偵されるとの仮定しており，圧子直下にプリズマ ティック転位ループを導入することで材料の塑性変形 を表現する. 同時に, 転位のバックストレスと弾性変 形分を重ね合わせすることによりナノインデンテー ション試験結果から弾塑性変形挙動をシミュレートす るものである(9).

このように，実験的に得られたナノインテンテー ション試験結果から転位分布を逆問題として解くこと により, 材料の降伏強度 - 塑性域形状・可逆一非可逆 的塑性仕事の分離・接触時の圧力分布等を算出するこ とが可能となる.

なお, 本手法の詳細な説明は紙面の都合上割愛する. 詳細な理論展開については文献 [10] を参照されたい.

4.2 数值解析および解析結果 図 3 のように压子 下の転位パンチングモデルを仮定する. 圧子の押込み によって表面の軸方向に三角形プリズマティック転位 ループを導入する. プリズマティック転位が動いた領 域が塑性域となり，転位ループは塑性域の境界上に分 布する. 塑性域断面形状は $x_{2}-x_{3}$ 平面内で次式で表 す半楕円を仮定した。

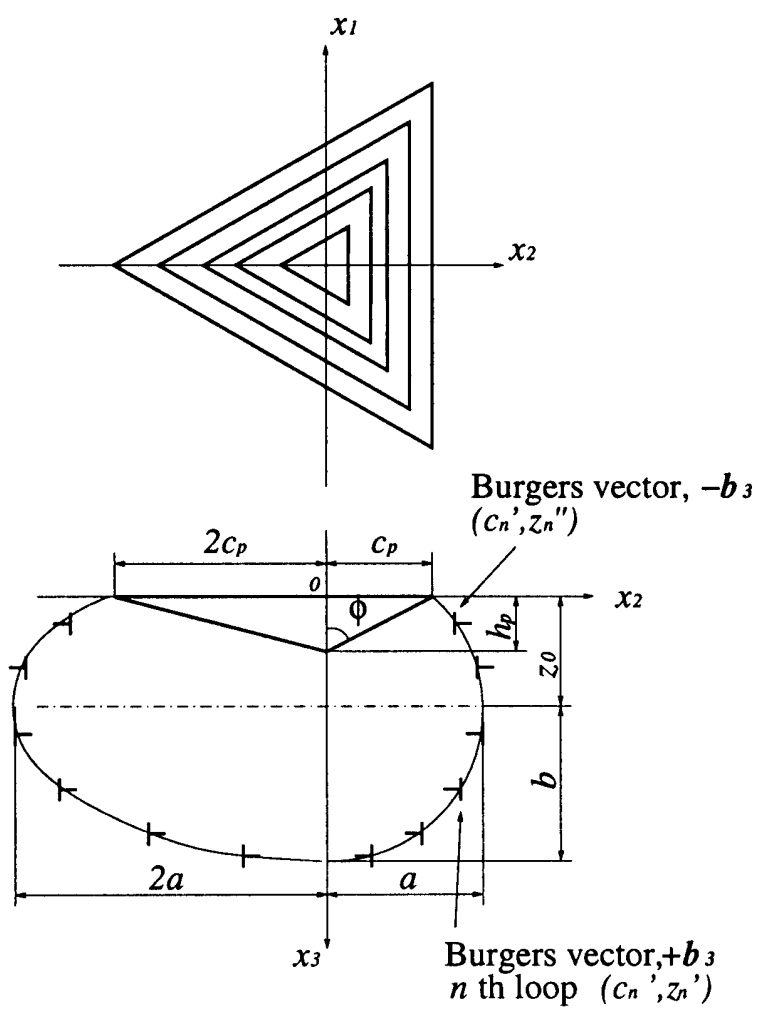

Fig.3 Schematic diagram of triangle prismatic dislocation loops and assumed distribution of dislocation on the semi-elliptical profile.

$$
\frac{x_{2}^{2}}{a^{2}}+\frac{\left(x_{3}-z_{0}\right)^{2}}{b^{2}}=1, x_{2}, x_{3} \geq 0
$$

ここで, $a, b$ および $z_{0}$ は材料および押込み状態に依存 する塑性域の形状パラメーターである.
計算は離散転位数 400 で行い，バーガースベクトル はその数と圧痕の大きさによって決まる．転位ループ は等間隔に配置し動かないものとした. $P_{\max }$ の計算は 三角形を 1300 個の等面積の長方形要素に分割し, 圧 力分布は各要素中心に作用する力として離散化した.

図 4 に $P_{\max }=500 \mathrm{mN}$ における実験結果より得ら れた荷重一押込み変位関係ならびに解析により得られ る除荷曲線を示す. 4.1 に示した一連の解析結果であ る除荷曲線は, 実験結果と良い一致を示すことが確認 できる，なお，材料および押込み状態に依存した塑性 域の形状パラメー夕は $\bar{a}=1.3, \bar{b}+\bar{z}_{0}=0.53$ を得た. つ づいて, 上記の形状パラメータにより予測される圧痕 直下の塑性域形状を図 5 に示す.

なお，他の試験荷重に対する解析および考察につい ては講演会当日に報告させていただく.

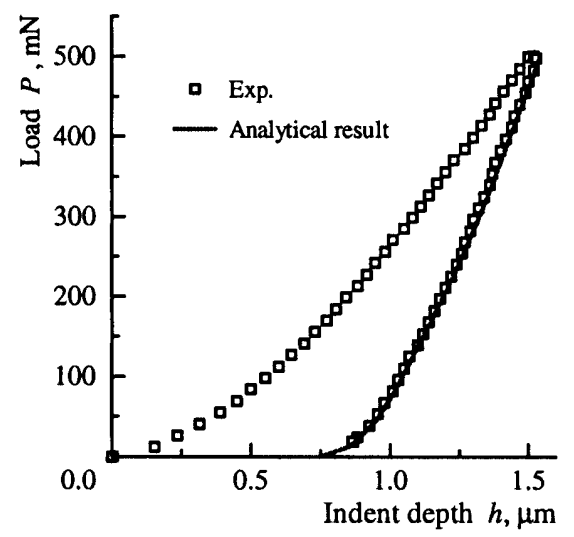

Fig.4 Experimental $P-h$ curve and analytical result predicted unloading curve.

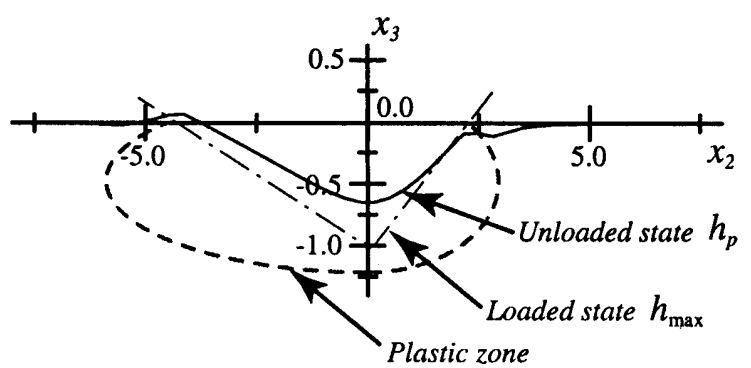

Fig.5 Cross-sectional view of analytical plastic zone.

\section{参考文献}

（1）吉川 弘之, 精密機械, 35-10(1969), 662.

(2) Nishioka, T. et al., J. Ceram. Soc. Japan, 103(1995), 335.

（3）江田他 3 名, 精密工学会誌, 62(1996), 236.

(4) Pethica, J. B. et al., Phil. Mag., A, 48(1983), 593.

(5) Doerner, M. F. and Nix, W. D., J. Mater. Res., 1(1986), 601.

(6) Ma, Q. and Clarke, D. R., J. Mater. Res., 104(1995), 853.

(7) Shibutani, Y. and Koyama, A., Proc. $14^{\text {th }}$ USNC$T A M,(2002), 348$.

(8) Oliver, W. C. and Pharr, G. M., J. Mater. Res., 7-6(1992), 1564.

(9) Tanaka, K. et al., Int. J. Engng. Sci., 27-1(1989), 11.

（10）金成 守康, 長岡技術科学大学 博士論文, (1997). 